Marquette University

e-Publications@Marquette

Finance Faculty Research and Publications

Finance, Department of

4-1-1995

Speed of Adjustment in Commercial Real Estate Markets

Mark Eppli

Marquette University, mark.eppli@marquette.edu

James D. Shilling

University of Wisconsin - Madison

Published version. Southern Economic Journal, Vol. 61, No. 4 (April 1995): 1127-1145. DOI. (C) 1995 Southern Economic Association. Used with permission.

Mark. J. Eppli was affiliated with George Washington University at the time of publication. 


\title{
Speed of Adjustment in Commercial Real Estate Markets
}

\author{
MARK J. EPPLI \\ George Washington University \\ Washington, D.C.
}

JAMES D. SHILLING

University of Wisconsin

Madison, Wisconsin

\section{Introduction}

The 1980s were less than favorable to the U.S. real estate industry. Vast amounts of overbuilding occurred in most areas and in most property types. Commercial vacancy rates increased dramatically and rents fell both in nominal and real terms. Untoward events (tax laws changes, deregulation of financial institutions, and a real estate depression in many areas of the country) virtually halted speculative development and caused a freefall in real estate prices. Real estate credit markets were crippled by the decade-long crisis in the S\&L industry and the federal government's handling of that crisis, while large pools of government-owned real estate sold at distressed prices. Employment decreases in the finance, insurance, and real estate industry, and corporate consolidations in the late 1980s reduced the number of jobs for the industries who would otherwise be tenanting empty office buildings. Finally, environmental issues significantly increased the uncertainties in real estate development and added to overall construction delays. Today, we begin the 1990s with an environment of soft real estate markets in most domestic locations, and among real estate developers the widespread belief is that this is not just another down cycle.

Given this recent past history, it seems like the perfect time to ask the question, How quickly do commercial real estate markets respond to changes in excess demand or supply? Traditionally, this problem has been known as the "speed of adjustment" problem, and it has been typically discussed in terms of stock-adjustment models of inventory investment $[1 ; 6 ; 21]$. Adjustment speeds are important for understanding future effects of real estate price changes and for interpreting recent events. The higher the adjustment speed, the greater the fraction of long-run adjustment experienced so far, the smaller the adjustments still to be expected, and the lower the implied long-run demand elasticity.

Adjustment speeds also have important implications for macroeconomic policy. There is reason to believe, for example, that the slow economic growth in the U.S. during the four years of the Bush administration was attributable, in large part, to the massive overbuilding that occurred in commercial property markets during the 1980s and the relatively slow process by which unemployed resources have been absorbed into productive new endeavors [16].

In what follows, we propose and test a stock-adjustment model of real estate investment. The 
model is tested with quarterly data on the stock of retail, office, and industrial real estate in the U.S. during the 1980:I-1990:II period. Then, the results are compared and contrasted to adjustment speeds prevailing in Canadian and U.K. real estate markets during approximately the same time period. Canadian and U.K. commercial property markets provide an interesting juxtaposition to U.S. commercial property markets given their strikingly different institutional relationships. Barkham and Geltner [2] note that, owing to greater homogeneity in England, U.K. commercial real estate markets are far more informationally efficient than in the U.S. Byrne and Goldberg [8] argue that differences between U.S. and U.K. commercial real estate cycles may arise as a result of dissimilarities in market size. We attribute the greater stability in Canadian and U.K. commercial property markets to a variety of factors.

\section{Market Adjustment Process for Commercial Real Estate}

There is a tendency to regard commercial real estate prices and rents as being relatively slow to adjust, and to assume that the quantity of space will adjust to equilibrate the market. Rosen and Smith [24], for example, have asserted that residential landlords react to fluctuations in demand primarily by building up or drawing down inventories of unlet space. Residential prices and rents are then affected but only after a lag.

A similar price-adjustment process for commercial real estate has been suggested by Shilling, Sirmans, and Corgel [27], and Voith and Crone [29]. They find that price adjustments are the strongest when the gap between the normal, long-run vacancy rate is the largest, and weakest when vacancies exceed the normal rate.

Wheaton [30], and Wheaton and Torto [32] have argued that commercial rents are determined by bargaining between landlords and tenants. Landlords set the minimum rent that they will accept based on an expected vacant time on the market. The expected vacant time decreases with the flow of prospective tenants and increases with the amount of competitive space available. Tenants set the maximum rent that they will pay based on the opportunities they have available to rent other space and on the competition they perceive from other prospective tenants. Actual rents are determined somewhere between the maximum that the tenant will pay and the minimum that the landlord will accept. Wheaton and Torto [32] further assume that, because landlords and tenants may be slow to perceive the flow of perspective tenants or the amount of competitive space on the market, the actual level of rents will adjust gradually to the desired rent level.

There is room for argument whether quantity adjustments clear the commercial property markets. Studies by Barth et al. [3], and Kling and McCue [19] find that there is a considerable lag in the supply response of new U.S. office construction to changing demand conditions. There is also some evidence of a weighty lag in the supply response of both industrial and retail real estate to changes in demand $[31 ; 20 ; 4]$.

This work, however, can be criticized for various reasons. Perhaps the most damning criticism has to do with the failure of these studies to correct for autocorrelation in estimating adjustment speeds. It has long been realized that slow adjustment speeds can result when stock-adjustment models are estimated without correcting for autocorrelation $[31 ; 20 ; 4]$. 


\section{A Stock-Adjustment Model of Commercial Real Estate}

To examine the speed of adjustment in commercial real estate markets, we adopt the following specification. We begin by writing the desired stock of retail, office, or industrial properties as

$$
K_{i t}^{*}=\Phi_{i} E_{i t}
$$

or

$$
K_{i t}^{*}=\beta_{i 0}+\beta_{i 1} E_{i t}+\varepsilon_{i t}
$$

where

$K_{i t}^{*}=$ the desired stock of capital,

$E_{i}=$ employment in industry $i$,

$\Phi=$ average square feet per employee, and

$\varepsilon_{i t}=$ random error term.

The subscript $i$ in this case refers to the retail, office, or industrial sector. ${ }^{1}$

Next, we write a stock-adjustment model for retail, office, and industrial properties as

$$
K_{i t}-K_{i t-1}=\delta_{i}\left(K_{i t}^{*}-K_{i t-1}\right) \quad 0<\delta_{i}<1
$$

where

$$
\begin{aligned}
K_{i t} & =\text { actual stock of capital, and } \\
\delta_{i} & =\text { the speed of adjustment parameter. }
\end{aligned}
$$

Equation (3) specifies that the change in $K_{i t}$ will respond only partially to the difference between the desired level of $K_{i t}^{*}$ and the past value of $K_{i t-1}$. The rate at which the market responds is the adjustment coefficient $\delta_{i}$. If $\delta_{i}$ equals one, then $K_{i t}^{*}$ equals $K_{i t}$ in each period and markets fully adjust each period (which would be indicative of a build-to-suit real estate market with no speculative construction). As $\delta_{i}$ becomes closer to zero, however, the longer it takes for real estate markets to equilibrate. This framework is developed in Blinder [6], and Maccini and Rossana [21], and many other papers.

Substituting equation (2) for $K_{i t}^{*}$ in (3) yields

$$
K_{i t}=\delta_{i} \beta_{0 i}+\delta_{i} \beta_{1 i} E_{i t}+\left(1-\delta_{i}\right) K_{i t-1}+\delta_{i} \varepsilon_{i t}
$$

or

$$
K_{i t}=\beta_{0 i}^{*}+\beta_{1 i}^{*} E_{i t}+\beta_{2 i}^{*} K_{i t-1}+\xi_{i t}
$$

where $\beta_{j i}^{*}=\delta_{i} \beta_{j i}(j=0,1), \beta_{2 i}^{*}=\left(1-\delta_{i}\right)$, and $\xi_{i t}=\delta_{i} \varepsilon_{i t}$.

Finally, and most important, it might be thought that the error term $\varepsilon_{i t}$ follows an $\operatorname{AR}(1)$ process. Hence, to estimate (5) we use the following two-step procedure. First, we estimate

1. The model in (1) is similar to the approach used by Birch [5] and others to forecast the demand for commercial real estate. 


$$
\begin{aligned}
K_{i t}= & \delta_{i}\left(1-\rho_{i}\right) \beta_{0 i}+\delta_{i} \beta_{1 i} E_{i t}-\rho_{i} \delta_{i} \beta_{1 i} E_{i t-1}+\left(\rho_{i}-\delta_{i}+1\right) K_{i t-1} \\
& -\rho_{i}\left(1-\delta_{i}\right) K_{i t-1}+e_{i t}
\end{aligned}
$$

or

$$
K_{i t}=\mu_{0 i}+\mu_{1 i} E_{i t}+\mu_{2 i} E_{i t-1}+\mu_{3 i} K_{i t-1}+\mu_{4 i} K_{i t-2}+e_{i t}
$$

From the coefficients of $E_{i t}$ and $E_{i t-1}$, we get an estimate of $\rho_{i}$, where $\hat{\rho}_{i}=-\mu_{i 2} / \mu_{i 1}$. We use this estimate of $\rho_{i}$ to construct $\hat{K}_{i t}=K_{i t}-\hat{\rho}_{i} K_{i t-1}$ and $\hat{E}_{i t}=E_{i t}-\hat{\rho}_{i} E_{i t-1}$, and then estimate

$$
\hat{K}_{i t}=\delta_{i}\left(1-\hat{\rho}_{i}\right) \beta_{0 i}+\delta_{i} \beta_{1 i} \hat{E}_{i t}+\left(1-\delta_{i}\right) K_{i t-1}+e_{i t}
$$

to get unique estimates of $\delta_{i}, \beta_{i 0}$, and $\beta_{i 1}$.

Note that in the likely event that the error terms $\xi_{i t}$ in (5) are correlated across the different real estate markets (i.e., adjustments made in one market, while moving it towards equilibrium, move the other markets away from equilibrium), we estimate (7) and (8) using Zellner's Seemingly Unrelated Regression technique. And where the error terms $\xi_{i t}$ in (5) are uncorrelated, then we obtain efficient estimates of $\delta_{i}, \beta_{i 0}$, and $\beta_{i 1}$ by performing ordinary least-squares estimation on each separate equation.

To account for the adjustment lags between $K_{i t}^{*}$ and $E_{i t}$, we adopted a sequential search process. ${ }^{2}$ This search process entailed estimating various versions of (5) with lagged values of $E_{i t}$ and choosing that lag structure for which the residual sum of squares was minimum. The reader is spared the laborious details of the many regressions that were run.

To control for the effect of climatic and institutional events that repeat more or less regularly each year, three seasonal 0-1 variables are added to (5): $S_{2}$ which takes on the value of 1 for the summer quarter and zero otherwise, $S_{3}$ which takes on the value of 1 for the fall quarter and zero otherwise, and $S_{4}$ which takes on the value of 1 for the winter quarter and zero otherwise.

\section{The Data}

Our measures of $K_{i t}$ and $E_{i t}$ are in dollar values, as opposed to physical units, and generally cover the period 1980:1-1990:2. Values of $K_{i t}$ are computed from the flow of funds accounts for the U.S., Canada, and the U.K. (see appendix for a more complete discussion). The data we analyze for $E_{i t}$ are from the National Income and Product Accounts (or National Income and Expenditure data) for the U.S., Canada, and the U.K. All flows are measured at quarterly rates.

Table I summarizes the value of new construction put in place and the excess returns on commercial real estate investments in the United States, Canada and the United Kingdom during the 1980:1-1990:2 period. Two major conclusions are suggested by the table. First, the 1980s were a period of rapid growth for real estate in the U.S. and Canada. Total construction put in place in the U.S. increased in real terms from $\$ 55,345$ million in 1980 to $\$ 78,229$ million in 1990

2. One can think of the lag between $K_{i t}^{*}$ and $E_{i t}$ as arising from the fact that most real estate developers are reluctant to cancel a project once it is started, even in the face of poor economic news. This reluctancy generally reflects the high transaction costs associated with real estate development. There is also an inherent built-in time delay between when the decision to go ahead with a project is made and the project's eventual completion date, which is likely to vary from region to region, or country to country depending on the complexity of the project and the time necessary to obtain government approvals. 
Table I. Value of New Construction Put in Place and Excess Quarterly Rates of Return on Real Estate by Property Type: United States, Canada, and United Kingdom, 1980-1990

\begin{tabular}{|c|c|c|c|c|c|c|c|c|c|c|c|c|c|}
\hline \multicolumn{7}{|c|}{ Value of New Construction Put in Place } & \multicolumn{7}{|c|}{ Excess Quarterly Rates of Return, \% } \\
\hline \multicolumn{3}{|c|}{$\begin{array}{l}\text { United States } \\
\text { (in \$ millions) }\end{array}$} & \multicolumn{2}{|c|}{$\begin{array}{c}\text { Canadab } \\
\text { (millions of } \\
\text { Canadian } \$ \text { ) } \\
\end{array}$} & \multicolumn{2}{|c|}{$\begin{array}{l}\text { United Kingdom }{ }^{c} \\
\text { (in } £ \text { millions) }\end{array}$} & \multicolumn{3}{|c|}{ United States d } & \multicolumn{2}{|c|}{ Canada ${ }^{\mathrm{e}}$} & \multicolumn{2}{|c|}{ United Kingdom $\mathrm{f}$} \\
\hline Retail & Office & Industrial & Retail & Office & Commercial & Industrial & Retail & Office & Industrial & Retail & Office & Commercial & Industrial \\
\hline 4624 & 5446 & 4492 & 330 & 684 & 616 & 522 & -0.34 & 0.96 & -0.44 & - & - & -0.57 & 0.35 \\
\hline 7019 & 7382 & 3737 & 409 & 848 & 754 & $499 *$ & 0.59 & -0.90 & 0.22 & $3.03 * *$ & $0.52 * *$ & -0.24 & -0.48 \\
\hline 7211 & 6627 & 4186 & 671 & 1191 & 1401 & 579 & 0.58 & -1.48 & 0.10 & 2.89 & 0.82 & 4.68 & 3.01 \\
\hline 6153 & 6464 & 4131 & 417 & 844 & 832 & 516 & 0.29 & -0.27 & 0.15 & 2.97 & 0.66 & 0.73 & 0.47 \\
\hline $56 \%$ & $22 \%$ & $-7 \%$ & $103 \%$ & $74 \%$ & $127 \%$ & $11 \%$ & - & - & - & - & - & - & - \\
\hline 1429 & 1166 & 678 & 185 & 273 & 354 & 154 & 1.02 & 2.18 & 0.84 & 1.08 & 2.13 & 2.99 & 3.36 \\
\hline
\end{tabular}

. U.S. Department of Commerce, Bureau of the Census, Value of New Construction Put in Place (expressed in 1987 dollars).

b. Statistics Canada, Building Permits, Monthly Survey (expressed in 1980 Canadian \$).

c. Department of the Environment, Great Britain, Housing and Construction Statistics (expressed in 1980 pounds).

d. FRC/NCREIF returns series.

e. Russell-Canadian returns series.

f. Weatherall, Green \& Smith returns series.

$*$ includes channel tunnel construction put in place.

**for the period $85: 1-87: 4$ 


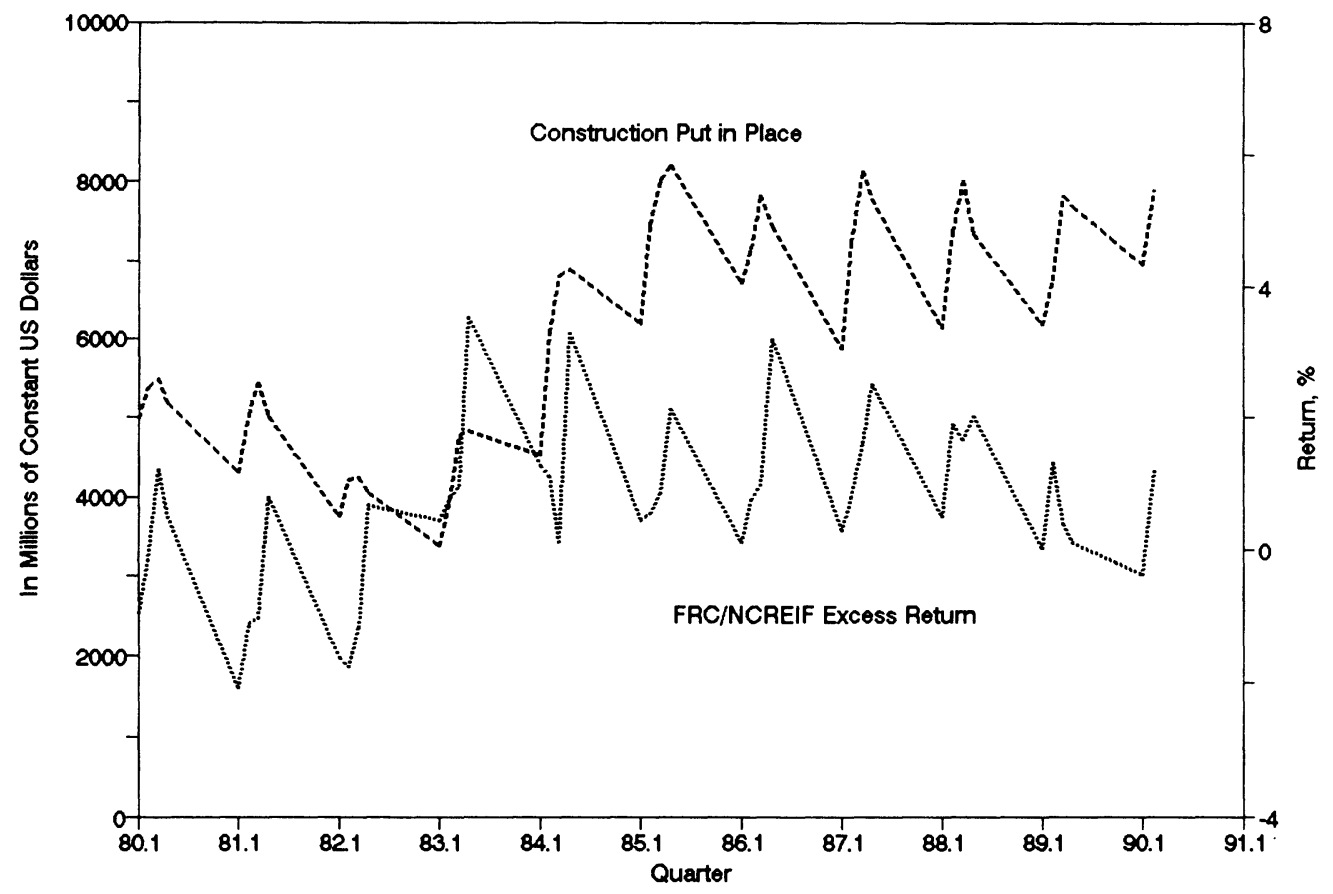

Figure 1A. U.S. Retail Construction and Excess Rates of Return, 1980-1990

(or a 41 percent increase). For Canada, total construction put in place increased in real terms from \$6,981 million (Canadian dollars) in 1980 to \$10,978 million (Canadian dollars) in 1990 (or a 57 percent increase). In comparison, total construction put in place in the U.K. increased in real terms from $£ 5,318$ million in 1980 to $£ 6,220$ million in 1990 (or a 17 percent increase).

Second, the rapid growth in office construction in the U.S. took place despite the fact that, as best as we can tell, investors were earning, on average, negative "excess returns" on office buildings. These quarterly returns are based on Frank Russell Company/National Council of Real Estate Investment Fiduciaries (FRC/NCREIF) less the risk-free rate and represent the performance of real estate investments made by large institutional investors. ${ }^{3}$ In contrast, excess rates of return in the U.K. averaged 0.73 percent per quarter for commercial properties and 0.47 percent per quarter for industrial properties during the period 1980:1-1990:2. Even more striking, excess rates of return in Canada averaged 2.97 percent per quarter for retail properties and 0.66 percent per quarter for office buildings during the period 1985:1-1990:2. Here the U.K. excess return series is taken from Weatherall, Green and Smith (WGS) less the risk-free rate and is constructed similar to the FRC/NCREIF returns index. The Canadian excess return series is the Russell-Canadian index less the risk-free rate.

Retail construction put in place in the U.S. increased significantly between the 1980:1-1983:4 and 1988:1-1990:2 periods (see Figure 1A). In the former period, the value of retail construction put in place in the U.S. averaged $\$ 4,624$ million per quarter; in the latter period the value of retail construction put in place in the U.S. averaged $\$ 7,211$ million per quarter (in constant 1987

3. Measurement errors are likely to occur in the FRC/NCREIF series since the returns are based on appraised values, not on market prices. See Giliberto [14] and Geltner [13] for a discussion of appraisal-based smoothing problems in the FRC/NCREIF returns series. 


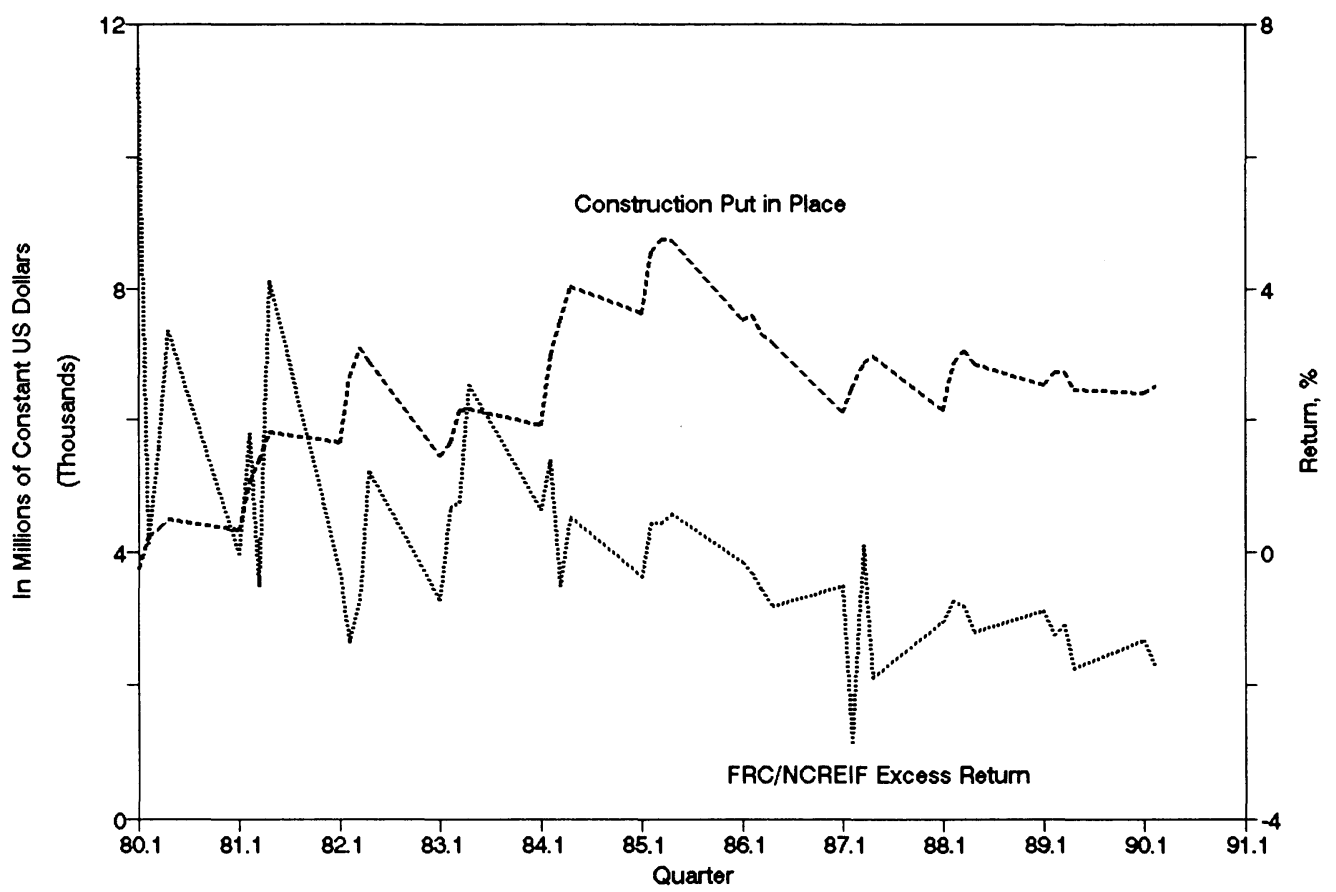

Figure 1B. U.S. Office Construction and Excess Rates of Return, 1980-1990

dollars) - an increase of 56 percent. The upward drift in the value of retail construction put in place in the U.S. begins around 1984:1-1984:2. The FRC/NCREIF retail excess rate of return series fluctuates considerably around 0.29 percent during the 1980:1-1990:2 period.

For the U.S., the relationship between office construction put in place and excess rates of return on office buildings is a far cry from that envisaged by Kling and McCue [19]. ${ }^{4}$ Office construction put in place in the U.S. increased from \$5,446 million per quarter in 1980:1-1983:4 to $\$ 6,627$ million per quarter in 1988:1-1990:2 (see Figure 1B). During the same time period, quarterly excess rates of return on office buildings in the U.S. fell from a high of 0.96 percent in 1980:1-1983:4 to a negative 1.48 percent in 1988:1-1990:2.

Industrial construction put in place in the U.S. declined from $\$ 4,492$ million in 1980:11983:4 to $\$ 3,737$ in 1984:1-1987:4 (see Figure 1C). Thereafter it increased sharply, even though the FRC/NCREIF industrial excess rate of return index decreased in 1988:1-1990:2.

Excess returns on Canadian real estate properties are only available over the 1985:1-1990:2 period. The Russell-Canadian excess returns for retail properties averaged 3.03 percent per quarter in the 1985:1-1987:4 period and 2.89 percent per quarter in 1988:1-1990:2 (see Figure 2A). For office properties in Canada, the average excess returns were 0.52 percent per quarter in 1985:11987:4 and 0.82 percent per quarter in 1988:1-1990:2 (see Figure 2B). Also notice that for Canada we restrict our attention to retail and office buildings.

Note that for the United Kingdom we have had to modify our definitions of non-residential real estate somewhat. The U.K. classifies non-residential real estate into two categories: commercial or industrial. Commercial real estate in this case includes income-producing property $[23 ; 31]$.

4. Others have noted that modeling office investment is difficult because office construction put in place is so variable 


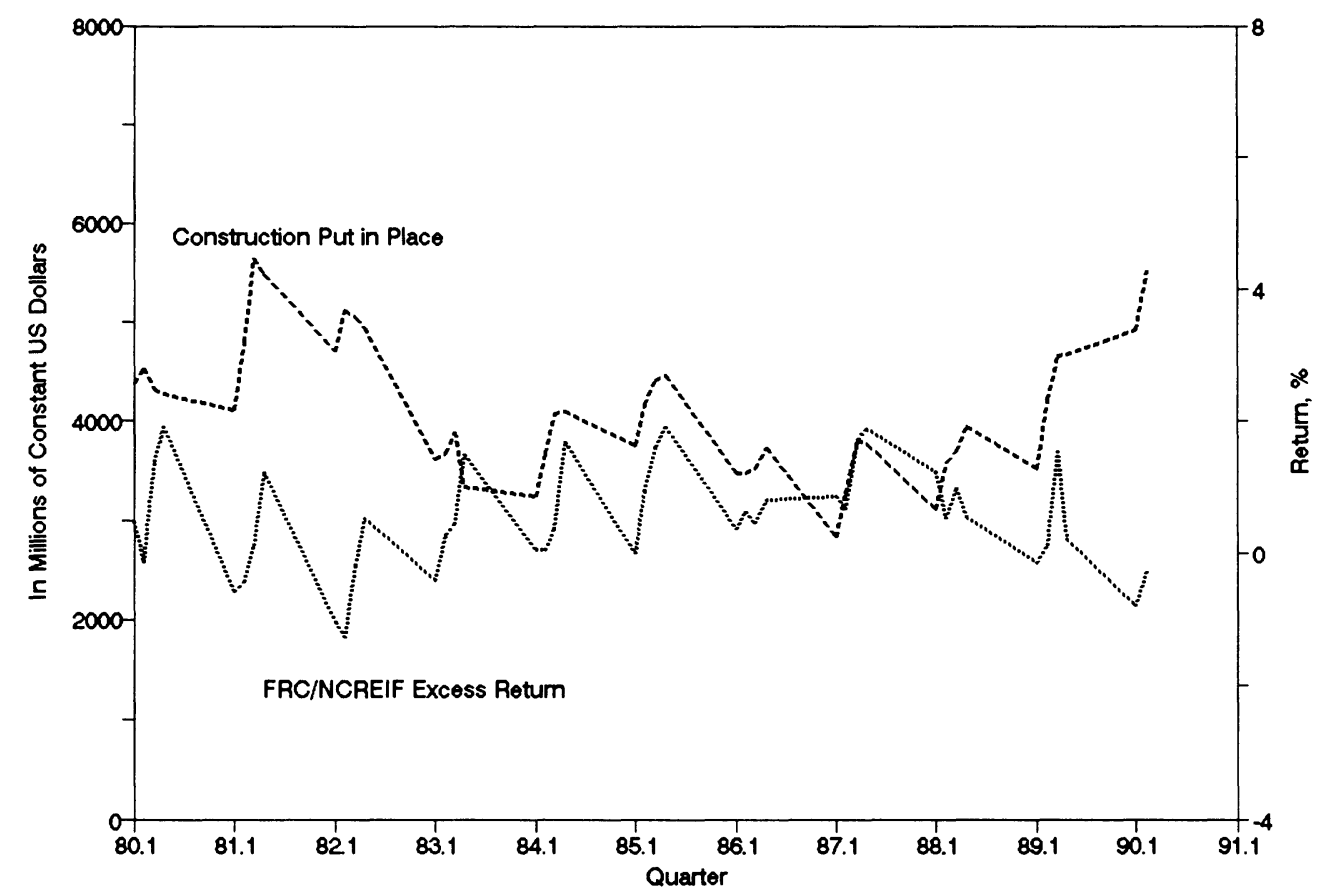

Figure 1C. U.S. Industrial Construction and Excess Rates of Return, 1980-1990

such as office buildings, restaurants, shopping centers, hotels and motels, and stores. Here again, industrial real estate includes buildings and structures at manufacturing sites.

For commercial properties in the U.K., the WGS excess returns index averaged a negative 0.57 percent per quarter in the 1980:1-1983:4 period (see Figure 3A). During the 1984:1-1987:4 period, the commercial excess returns series averaged -0.24 percent per quarter. In 1988:1-1990:2, the commercial excess returns series averaged 4.68 percent per quarter.

Interesting enough, performance of industrial real estate in the United Kingdom during the 1980s stands in marked contrast to that of industrial real estate in the United States. Excess returns on industrial properties were 0.35 percent per quarter in 1980:1-1983:4; decreased to a negative 0.48 percent per quarter in 1984:1-1987:4 and then increased markedly to 3.01 percent per quarter in 1988:1-1990:2 (see Figure 3B).

\section{Estimation Results}

Results of estimating (5) for U.S. retail, office, and industrial markets are provided in Table II, with standard errors shown in parentheses. Column (1) is estimated using ordinary least squares. Columns (2) and (3) are estimated using our two-step estimation procedure to correct for serial correlation.

A few brief comments about Table II seem in order. First, the coefficient of $E_{t-x}$, where $x$ refers to a $x$-period lag, suggests that it takes between eight and twelve quarters for U.S. retail, office, and industrial markets to detect a change in the desired $K_{i t}$ and then to alter the actual $K_{i t}$. This adjustment lag suggests that construction activity in the U.S. is relatively slow to react to economic shocks. 


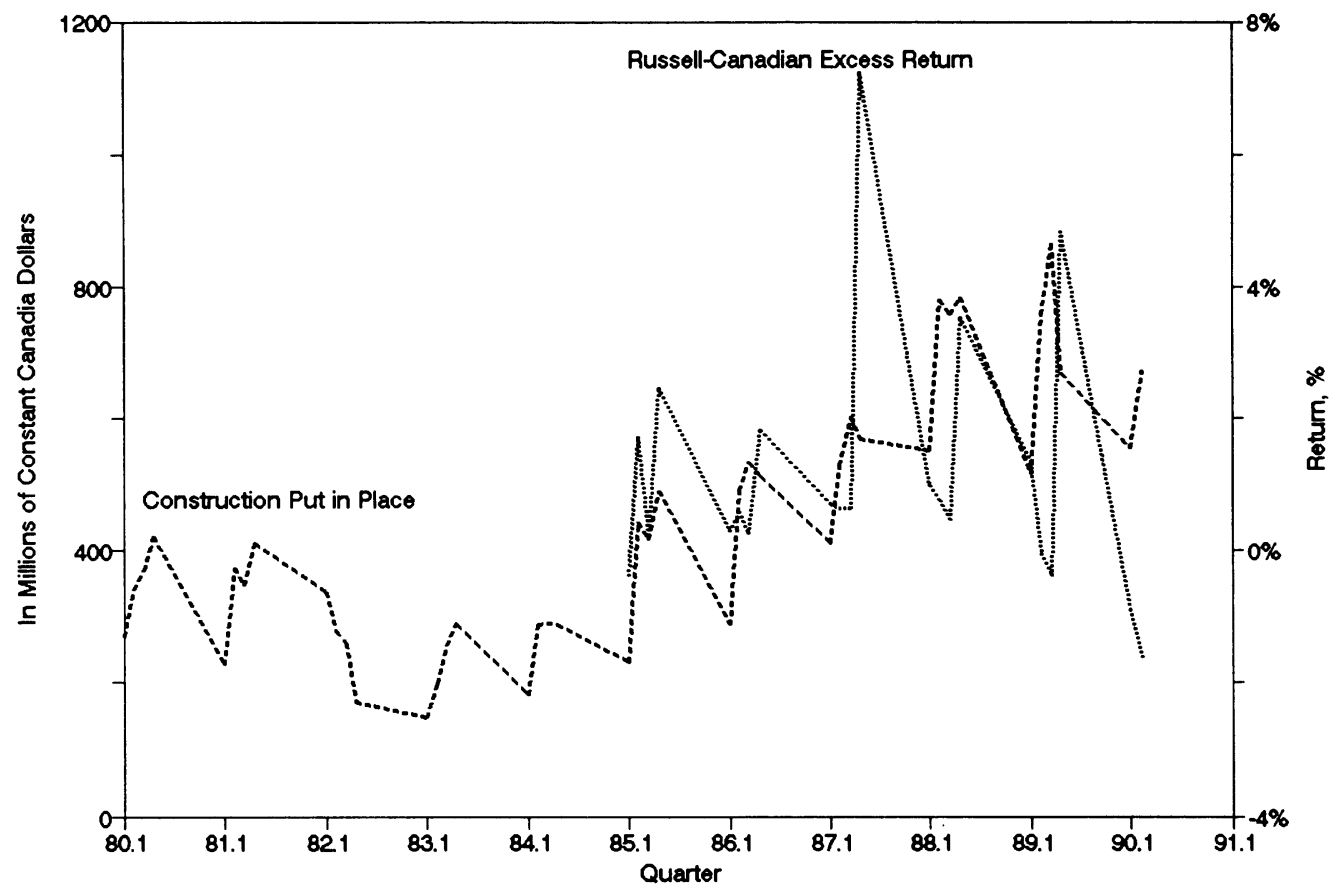

Figure 2A. Canadian Retail Construction and Excess Rates of Return, 1980-1990

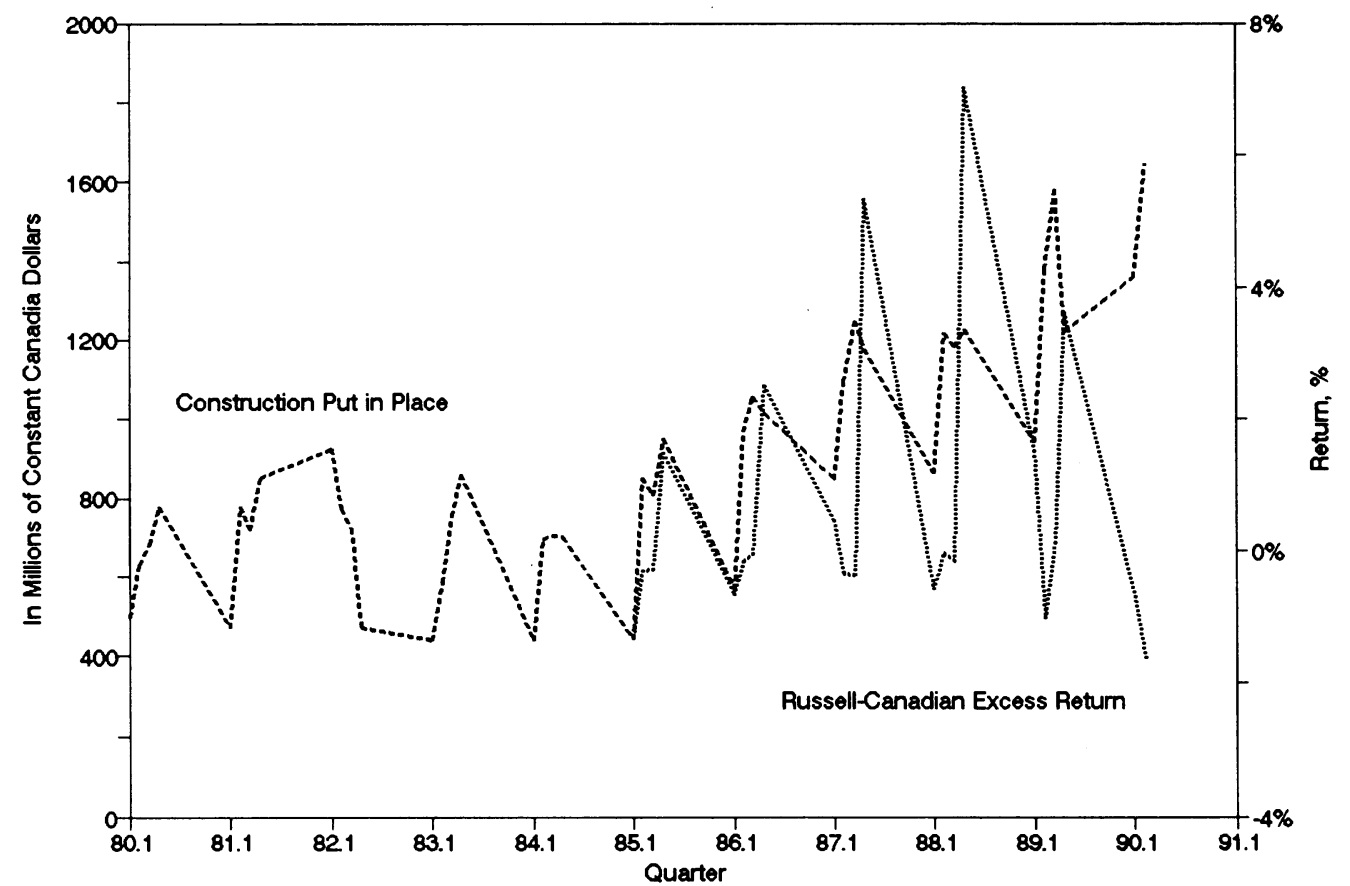

Figure 2B. Canadian Office Construction and Excess Rates of Return, 1980-1990 


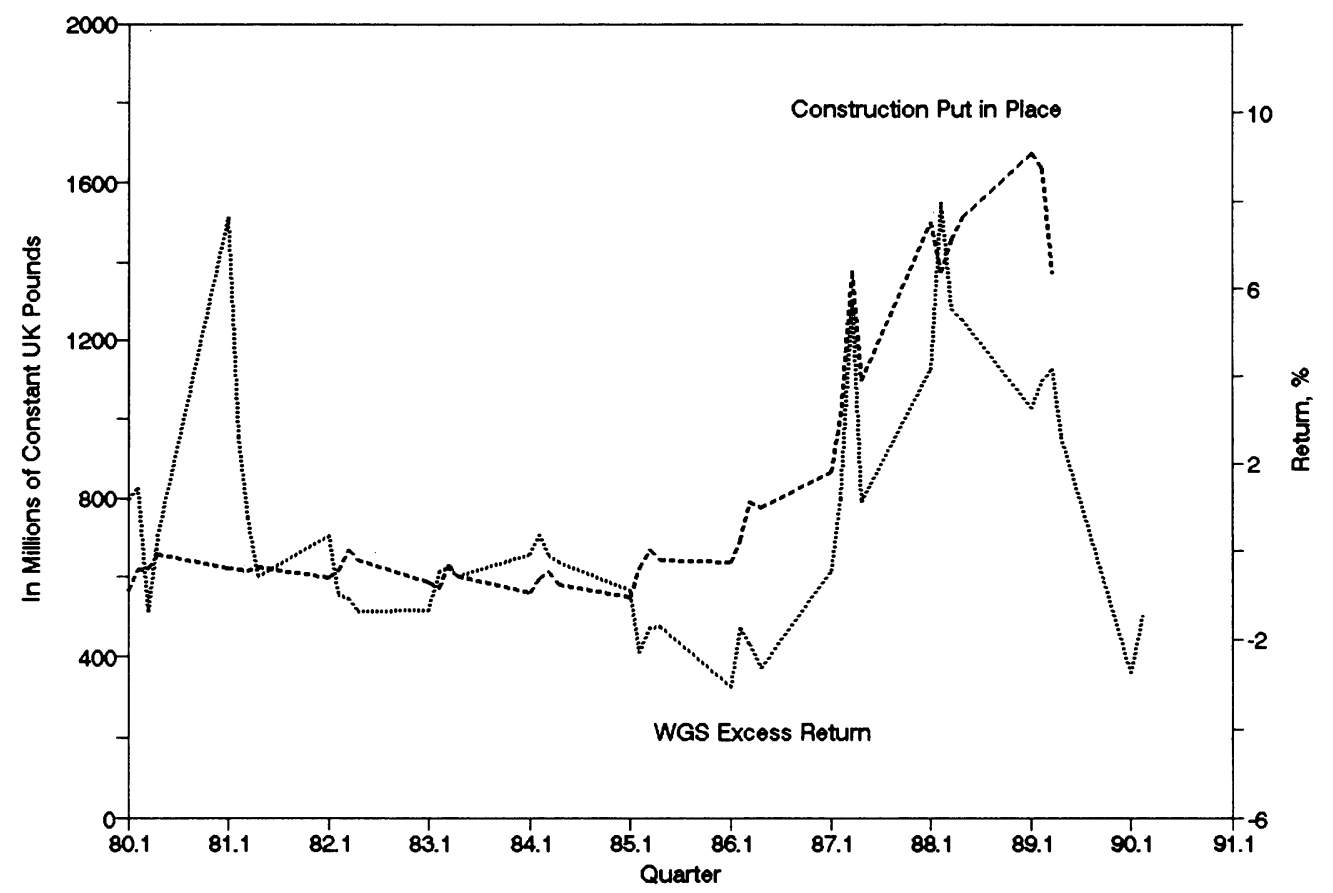

Figure 3A. U.K. Commercial Construction and Excess Rates of Return, 1980-1990

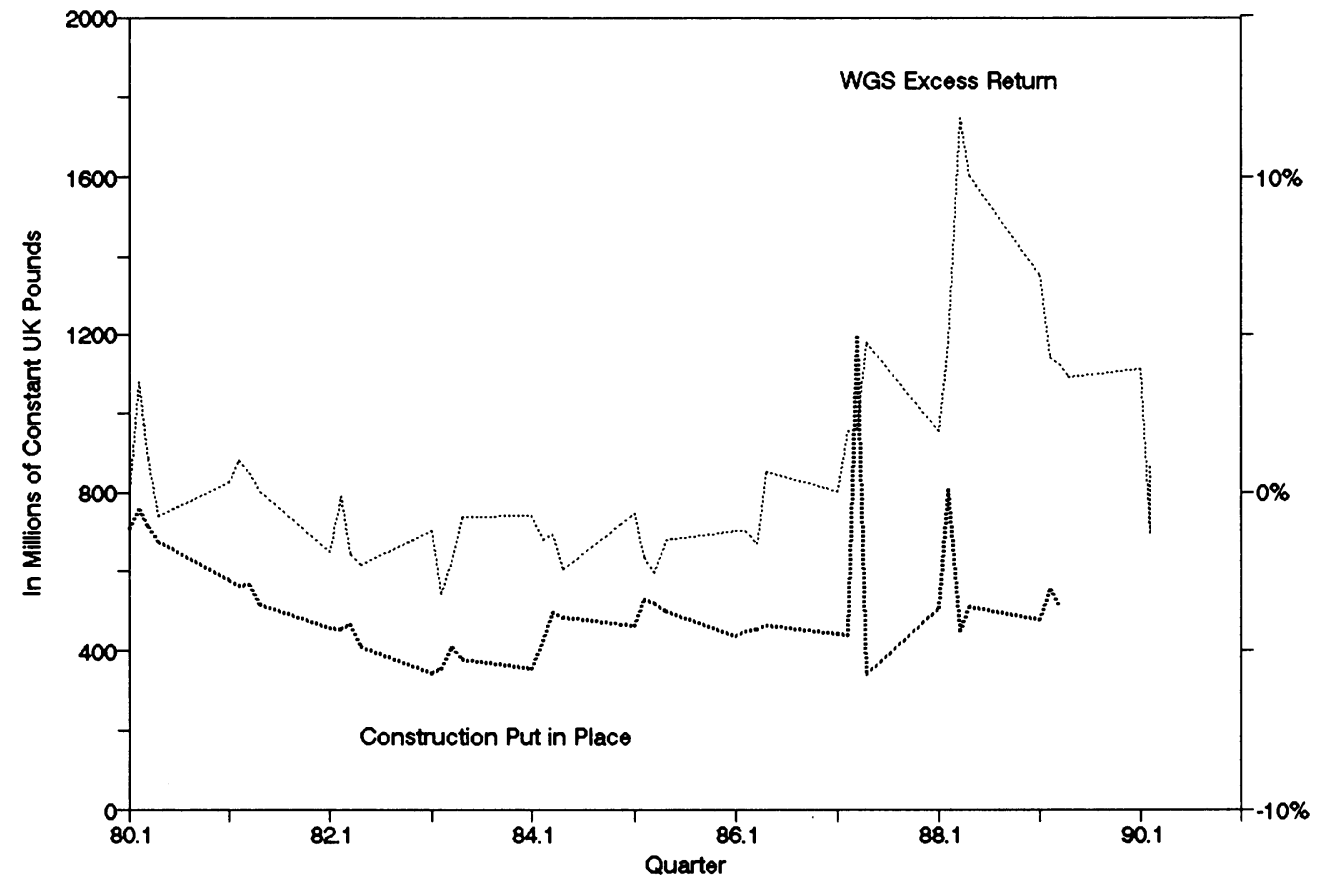

Figure 3B. U.K. Industrial Construction and Excess Rates of Return, 1980-1990 
Table II. Determinants of Speed of Adjustment in U.S. Real Estate Markets (figures in parentheses are standard errors)

\begin{tabular}{lccc}
\hline & \multicolumn{3}{c}{ Property Type } \\
\cline { 2 - 4 } Variable & Retail & Ordinary-Least Squares Estimates & Office $^{\text {a }}$ \\
\hline$\beta_{0}^{*}$ & $x=12$ & $x=8$ & $x=12$ \\
\hline$E_{t-x}$ & -2584 & 5372 & -12620 \\
& $(3095)$ & $(4639)$ & $(7291)$ \\
$K_{t-1}$ & .0324 & .0426 & .0386 \\
& $(.01)$ & $(0.01)$ & $(0.01)$ \\
$S_{2}$ & .9608 & .7306 & .4504 \\
& $(0.02)$ & $(0.04)$ & $(0.03)$ \\
$S_{3}$ & -1718 & -1776 & -1847 \\
& $(1132)$ & $(1086)$ & $(1250)$ \\
$S_{4}$ & -1255 & -742 & -885 \\
& $(1160)$ & $(1107)$ & $(1267)$ \\
Summary Statistics: & -1996 & -2050 & -2475 \\
$\delta$ & $(1160)$ & $(1105)$ & $(1267)$ \\
$\rho$ & & & .5496 \\
$R^{2}$ & .0392 & .2694 & .5548 \\
Root MSE & -1970 & .9261 \\
$h$-value & 0.9967 & .9961 & 2825 \\
$N$ & 2652 & 2468 & - \\
\hline & 0.41 & - & 41 \\
\hline
\end{tabular}

a. Adjusted for serial correlation (see text).

Second, the estimated short-run income elasticities for U.S. retail, office, and industrial properties are $0.07,0.08$, and 0.10 , respectively. And the estimated long-run income elasticities are $1.68,0.31$, and 0.19 , respectively. These elasticities are measured in the usual way. ${ }^{5}$

Third, as might be expected, the estimated speeds of adjustment are much slower for U.S. retail properties than for U.S. office and industrial buildings. This contention arises because most retail properties possess spatial monopolies to some degree either in fact or in the mind of the consumer. And so retail properties, in general, tend to be much more insulated from increased competition than office and industries properties. Adjustment speeds for U.S. retail, office, and industrial properties also depend on the rate of economic growth within each sector. Faster economic growth generally implies a more rapid adjustment whenever new capital stock is more efficient than old.

Our estimate of the speed of adjustment of $K_{i t}$ to $K_{i t}^{*}$ for U.S. retail properties is 0.0392 (that is, 3.92 percent per quarter). In contrast, the $\delta_{i}$ point estimate for the U.S. office market is 26.94 percent per quarter (see column (2)). And for U.S. industrial properties, the $\delta_{i}$ point estimate

5. We calculate the short-run and long-run elasticities as

$$
\eta_{S R}=\beta_{i 1}^{*}\left(\bar{E}_{i} / \bar{K}_{i}\right) \text { and } \eta_{L R}=\beta_{i 1}^{*} /\left(1-\beta_{i 2}^{*}\right)\left(\bar{E}_{i} / \bar{K}_{i}\right)
$$


Table III. Determinants of Speed of Adjustment in Canadian Real Estate Markets (figures in parentheses are standard errors)

\begin{tabular}{lcc}
\hline & & \multicolumn{2}{c}{ Property Type } \\
& \multicolumn{2}{c}{ SUR Estimates Adjusted for Serial Correlation } \\
\cline { 2 - 3 } Variable & Retail & Office \\
\hline$\beta_{0}^{*}$ & $(x=4)$ & $(x=4)$ \\
\hline$E_{t-x}$ & 3735 & 2167 \\
& $(1023)$ & $(1799)$ \\
$K_{t-1}$ & 0.1148 & .1185 \\
& $(0.02)$ & $(0.03)$ \\
$S_{2}$ & .1966 & .3170 \\
& $(0.02)$ & $(0.02)$ \\
$S_{3}$ & 139 & 211 \\
& $(73)$ & $(111)$ \\
$S_{4}$ & 129 & 308 \\
& $(75)$ & $(114)$ \\
Summary Statistics: & 116 & 277 \\
$\delta$ & $(75)$ & $(114)$ \\
$\rho$ & & \\
$R^{2}$ & .8034 & .6830 \\
Root MSE & .7059 & .6409 \\
$h$-value & .9448 & .9786 \\
$N$ & 175 & 265 \\
\hline
\end{tabular}

is 54.96 percent per quarter (see column (3)); more than fourteen times that of the speed of adjustment for U.S. retail properties. ${ }^{6}$

Our results for Canadian real estate markets are shown in Table III. Both equations in Table III are based on Zellner's Seemingly Unrelated Regression technique adjusted for serial correlation. Standard errors are shown in parentheses. Overall, the findings suggest that Canadian real estate markets adjust much quicker to shocks in $K_{i t}^{*}$ than U.S. real estate markets.

The estimates of $\beta_{i 1}^{*}$ in Table III imply a long-run income elasticity of $K_{i t}$ with respect to income of 0.12 for Canadian retail properties and 0.09 for Canadian office buildings. Thus, in a given year a 10 percent decline in income translates into a 1.2 percent decrease in $K_{i t}$ for Canadian retail properties and a 0.9 percent decrease in $K_{i t}$ for Canadian office buildings, both after a relatively short adjustment lag. The short-run income elasticities for Canadian retail and office buildings are 0.09 and 0.06 , respectively.

Regression results for U.K. real estate markets are shown in Table IV. Note that the parameter estimates are based on Zellner's Seemingly Unrelated Regression technique unadjusted for serial correlation. Again, standard errors are presented in parentheses.

The estimated speed of adjustment is 3.93 percent per quarter for U.K. commercial proper-

6. To test Brueckner and Pereira's [7] hypothesis that wealth losses exacerbate the impact on $K_{i t}-K_{i t-1}$, we also included the variable $\Delta p K_{i t-1}$ in (5), where $p_{i t}$ is the market valuation of real estate (taken from the FRC/NCREIF real estate index). Generally, the variable $\Delta p K_{i t-1}$ had no statistical effect on $K_{i t}$. Similar results (not reported here) were found for Canadian and U.K. real estate markets. 
Table IV. Determinants of Speed of Adjustment in U.K. Real Estate Markets (figures in parentheses are standard errors)

\begin{tabular}{lcc}
\hline & \multicolumn{2}{c}{ Property Type } \\
\cline { 2 - 3 } Variable & $\begin{array}{c}\text { Commercial } \\
(x=8)\end{array}$ & $\begin{array}{c}\text { Industrial } \\
(x=8)\end{array}$ \\
\hline$\beta_{0}^{*}$ & 9977 & 5839 \\
& $(20829)$ & $(11535)$ \\
$E_{t-x}$ & .0196 & .0094 \\
$K_{t-1}$ & $(0.05)$ & $(0.03)$ \\
& .9607 & .9599 \\
$S_{2}$ & $(0.06)$ & $(0.6)$ \\
$S_{3}$ & 1104 & 692 \\
& $(22332)$ & $(12427)$ \\
$S_{4}$ & -941 & -411 \\
& $(21865)$ & $(12168)$ \\
Summary Statistics: & -30062 & -16674 \\
$\delta$ & $(21891)$ & $(12184)$ \\
$\rho$ & & .0401 \\
$R^{2}$ & .0393 & - \\
Root MSE & - & .8292 \\
$h$-value & .8256 & 29142 \\
$N$ & 52370 & .32 \\
\hline & .30 & 46 \\
\hline
\end{tabular}

ties and 4.01 percent for U.K. industrial properties. The estimated short-run income elasticities for U.K. commercial and industrial properties are 0.01 and 0.008 , respectively. And the estimated long-run income elasticities are 0.24 and 0.20 , respectively. The estimate of $\beta_{i 1}^{*}$ also suggests that it takes, on average, eight quarters for U.K. commercial and industrial markets to detect a change in the desired $K_{i t}$ and then to alter the actual $K_{i t}$.

In general, the points to note about these results are (1) most commercial property markets suffer from a relatively long adjustment lag, and (2) contrary to the more recent theory on price-adjustment and market dynamics, quantity adjustments in commercial real estate markets are fairly sluggish.

\section{Simulated Real Estate Cycles}

We now wish to illustrate the implications of the models estimated in section V. To do so, we simulate the impact of a 10 percent reduction in income on $K_{i t}$ under the following assumptions. First, we assume that once $K_{i t}$ adjusts to the new $K_{i t}^{*}$ it will stay there indefinitely, under the assumption of constant demand and supply. We also assume that oscillations about the equilibrium value of $K_{i t}$ occur as the lagged-supply response works through the models. The cycle attenuates given sufficient time and, as eventual equilibrium is reached, the cycle ceases to exist.

Figure 4 presents the results of our simulations for U.S. real estate markets. The percent deviations from the steady-state $K_{i t}$ that are shown in Figure 4 depend significantly on the estimated 


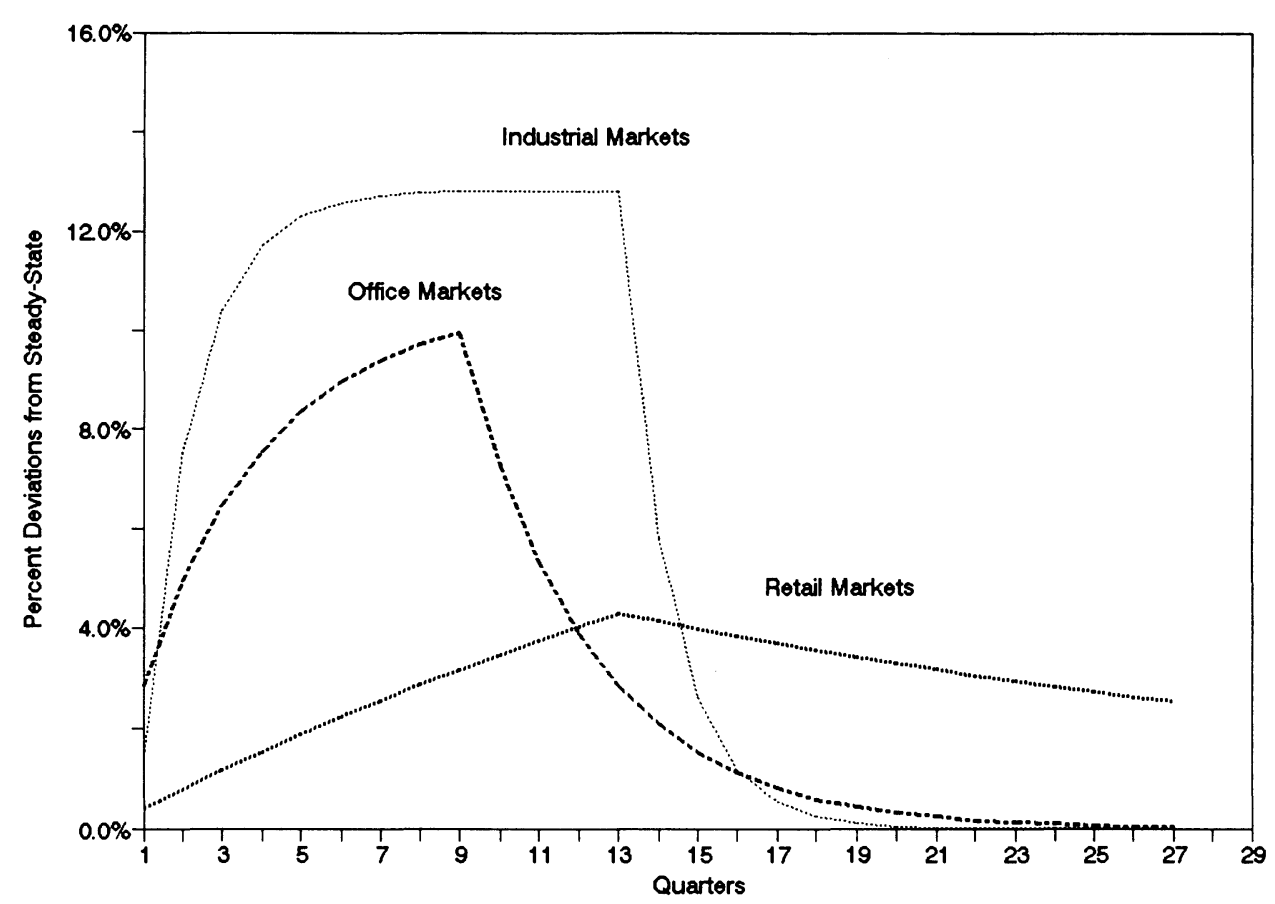

Figure 4. Overbuilding Caused by a $10 \%$ Reduction in $Y$ : U.S. Real Estate

income elasticities and the observed adjustment speeds. Relatively slow adjustment speeds, for example, will tend to cause moderately flat real estate cycles. Relatively fast adjustment speeds, on the other hand, will tend to cause rather abrupt cycles and large social costs.

For the U.S. office market, our simulations suggest that, after the adjustment lag, it takes about two years for the adjustment of the actual stock to be 90 percent complete. The corresponding adjustment period for the U.S. industrial real estate market is less than one year. For retail properties, the adjustment period is in excess of ten years. ${ }^{7}$

An interesting contrast to these adjustment speeds is provided by Muth [22]. Muth finds that the adjustment period in the U.S. housing market is roughly six years. Rydell [25], on the other hand, finds that there is a 90 percent adjustment in the stock of housing within three years. Rydell also finds that the extent of the adjustment period depends upon the vacancy rates in the markets. At higher vacancy rates, the short-run effect of price is smaller and the long-run effect on quantity of housing services consumed is much higher.

Along these same lines, anecdotal evidence suggests that the adjustment speed for U.S. office buildings increased from six years of extra supply in 1988 to twelve years in 1991 [26]. Adjustment speeds for U.S. industrial and retail properties are much harder to document. Kling and McCue [20], using a vector autoregression model, document that macroeconomic variables affect industrial construction with a lag and that this lag is generally shorter than those reported for office properties.

7. Note that these findings have nothing to say about the variation in the speed of adjustment among U.S. retail, office, and industrial real estate markets. To do so, it would be desirable to estimate equation (5) with data from the particular local real estate market to obtain the speed of adjustment for that market. 


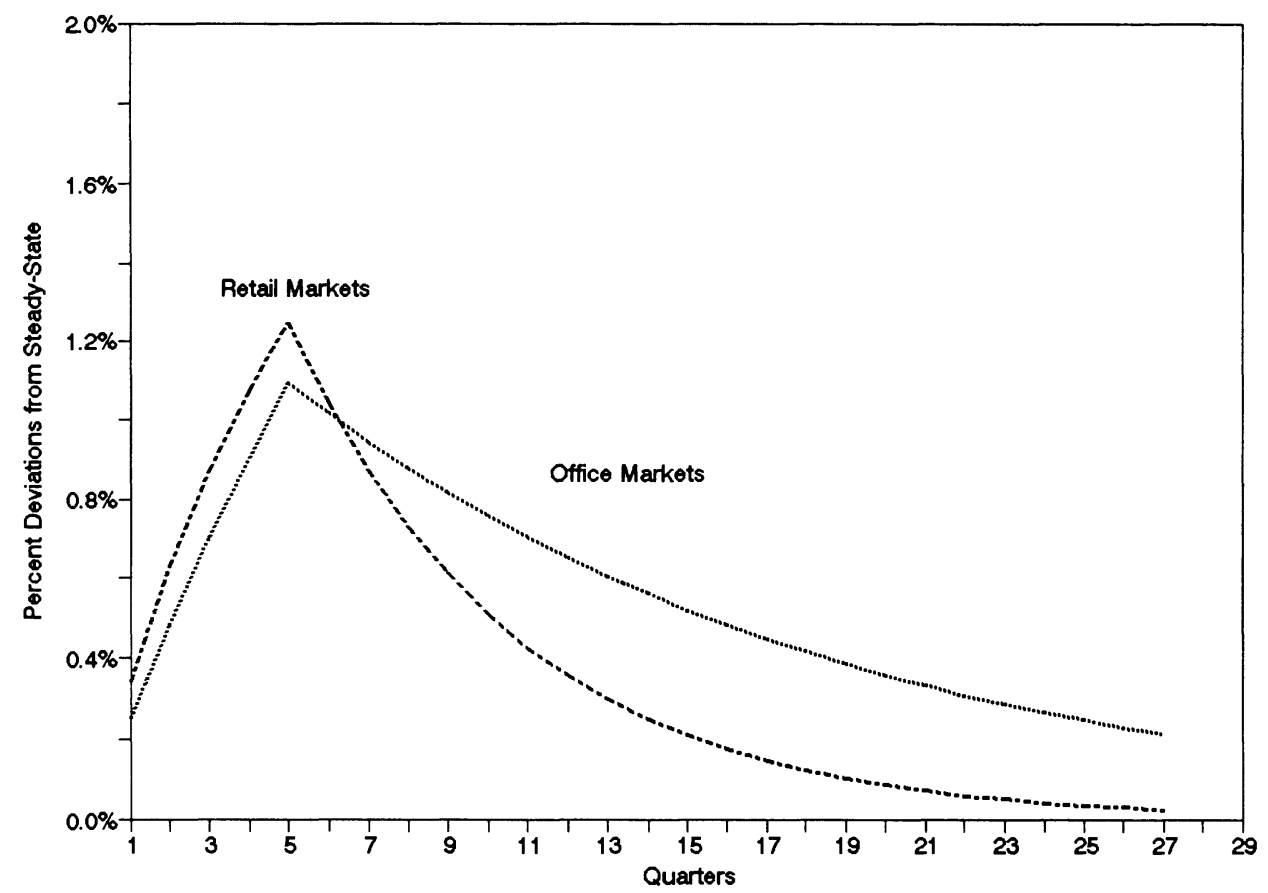

Figure 5. Overbuilding Caused by a $10 \%$ Reduction in $Y$ : Canadian Real Estate

For Canadian real estate markets, our simulations suggest that the real estate cycles are much less sensational than U.S. real estate cycles - meaning the percent deviations from steady-state are much lower (see Figure 5). Also of central interest is the fact that approximately 90 percent of the excess supply in both Canadian retail and office markets is worked off in less than one year.

We further notice that U.K. real estate cycles are, by far, the most sedate (see Figure 6). The percent deviations from steady-state for U.K. commercial or industrial real estate never exceed $1 / 2$ of one percent. Our simulations also suggest that with U.K. investors seeking to add about one-sixth of the difference between desired and actual stock during a year, for the adjustment of the actual stock of U.K. commercial and industrial real estate to be 90 percent complete, roughly fourteen years are required.

\section{Explanations for the Abrupt Real Estate Cycles in the U.S. during the 1980s}

The most likely explanation of the abrupt real estate cycles in the U.S. during the 1980s is that they were caused by a variety of factors. Hendershott and Kane [16] argue that the decade-long crisis in the S\&L industry and U.S. federal government's handling of that crisis created a lending frenzy in the U.S. during the 1980s, and that this lending frenzy led to vast amounts of overbuilding in U.S. real estate markets as many developers lost sight of demand and supply factors.

A second seemingly possible explanation for the abrupt real estate cycles in the U.S. during the 1980s is Keynes's [18] bounded rationality argument. For a recent discussion of this literature applied to real estate, see De Bondt [12].

A third explanation of the abrupt real estate cycles in the U.S. during the 1980s asserts that 


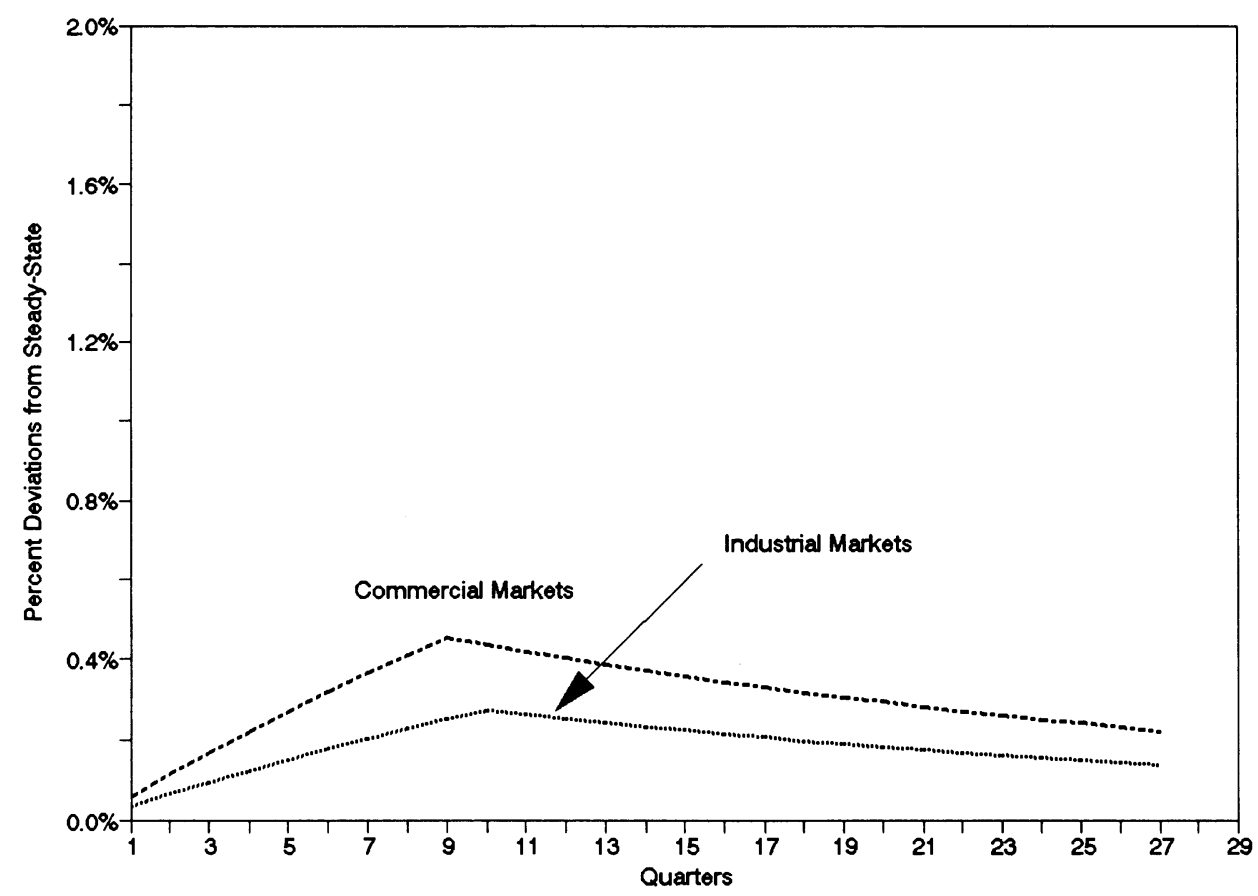

Figure 6. Overbuilding Caused by a $10 \%$ Reduction in $Y$ : U.K. Real Estate

pro-development attitudes like those in many metropolitan areas in the U.S. tend to encourage overbuilding, whereas controlled growth environments like those in Canada and the U.K. tend to foster a positive investment climate in the long-run.

As another possibility, U.S. real estate markets during the 1980s may have responded rationally to large negative demand shocks. Cauley [10] notes that, after a negative demand shocklike a change in tax laws as a restructuring and downsizing of the consumer, office, and defense sectors of the economy, all of which occurred in the U.S. during the 1980s - investors will typically wait until the price uncertainty is resolved to transact. This decline in asset liquidity, if substantial enough, can easily account for an abrupt real estate cycle.

Many of the international differences in real estate cycles may also arise as a result of dissimilarities in market size. For a more complete discussion of the relationship between real estate cycles and market size, see Bryne and Goldberg [8].

\section{Events Since 1990}

Events since 1990 suggest that there have been marked changes in Canadian and U.K. commercial real estate markets. Canadian commercial real estate markets, for example, appear at the moment to be vastly overbuilt. Greater metropolitan Toronto's year-end 1992 vacancy rate of 18.2 percent represents a high watermark in the market's vacancy problem. Montreal's overall office vacancy rate increased from 12.8 percent in 1990 to 17.9 percent in 1992. Ottawa's 1992 office vacancy rate is 12.1 percent, while office vacancies in Calgary, Edmonton, and Vancouver are currently in the 13 to 20 percent range. 
U.K. commercial real estate markets also appear at the moment to be vastly overbuilt. Office vacancy rates in London's City and West End, for example, now exceed 15 percent. As a consequence of the excess supply and slow absorption of commercial space, property values have fallen and building yields (rents divided by capital values) have increased significantly. Currently, building yields are over 9 percent - a historical high. These events predict a marked reduction in adjustment speeds for Canadian and U.K. real estate markets.

In the U.S., it is really much too early to tell whether or not returns from commercial real estate investments have bottomed out. During the past few years, new construction in the U.S. has slowed dramatically as lenders, wary of the excesses of the 1980 s, have been very reluctant to finance real estate developments. ${ }^{8}$ There are also signs that real estate markets have matured from one where developers-investors typically built for their own portfolios into one where institutional investors - like in the U.K. - are the driving force behind the merchant builder. Still, vacancy rates for office space hover in the 15-20 percent range, with some cities above 25 percent. Demand in the retail, office, and industrial areas remains weak in most markets and real returns on commercial real estate are at all-time lows.

\section{Concluding Comments}

In the literature, it is frequently asserted that commercial real estate prices and rents move sluggishly toward equilibrium, leaving the quantity of space to act as a market clearer. Our results cast some serious doubts on this proposition. First, we find that quantity adjustments in U.S. commercial property markets respond with a relatively long lag before changes in the desired new capital stock are taken into account. We also find that, once the desired new capital stock is phased-in, the adjustment period is far from instantaneous. For U.S. office and industrial real estate markets, for example, the adjustment period ranges from one to two years. For U.S. retail property markets, the adjustment period is significantly longer. It should also be emphasized that, taken together, these results suggest that commercial property markets in the U.S. are susceptible to pronounced boom-and-bust cycles.

Somewhat faster adjustment speeds with relatively shorter adjustment lags are found for Canadian commercial property markets. In U.K. real estate markets, we find noticeably slower adjustment speeds. Most conspicuous in both Canadian and U.K. commercial property markets is the responsiveness of commercial real estate to changes in income. Rather than observing periods of substantial overbuilding followed by periods of little, or no, growth, we find much greater stability in both Canadian and U.K. commercial property markets (at least through the end of 1990).

\section{Appendix. Variables and Data Sources}

The following variables appear in the text.

\section{United States:}

$K_{i t}=$ outstanding stock of commercial real estate (in \$ millions), constructed using a perpetual inven-

8. The passage of the Financial Institutions Regulatory Reform and Enforcement Act (FIRREA) of 1989 and comparable tightening of capital requirements on commercial banks has also played a major role in the continued decline of commercial construction put in place during the last few years. 
tory technique with a constant economic depreciation rate fitted for data from the Commerce

Department, Fixed Reproducible Tangible Wealth in the United States, 1925-1985.

$E_{i t}=$ employment in industry $i$ (in \$ millions), from National Income and Product Accounts.

\section{Canada:}

$K_{i t}=$ outstanding stock of commercial real estate (in millions of Canadian \$), constructed using a perpetual inventory technique with a constant economic depreciation rate fitted for data from Statistics Canada, Fixed Capital Flows and Stocks, 1987.

$E_{i t}=$ employment in industry $i$, index numbers at constant factor costs, from Statistics Canada.

\section{United Kingdom:}

$K_{i t}=$ outstanding stock of commercial real estate (in $£$ millions), constructed using a perpetual inventory technique with a constant economic depreciation rate fitted for data obtained from the National Accounts Statistics: Main Aggregates and Detailed Tables, 1988.

$E_{i t}=$ employment in industry $i$ (in $£$ millions), from National Income and Expenditure data.

\section{References}

1. Bar-Ilan, Avner and Alan S. Blinder, "Consumer Durables: Evidence on the Optimality of Doing Nothing." Journal of Money, Credit, and Banking, May 1992, 258-72.

2. Barkham, Richard and David Geltner, "Price Discovery in American and British Property Markets." AREUEA Journal, Spring 1995.

3. Barth, James R., Michael D. Bradley, Joseph A. McKenzie, and G. Stacey Sirmans. "Stylized Facts about Housing and Construction Activity during the Post-World War II Period," in Real Estate Market Analysis: Methods and Applications, edited by J. M. Clapp and S. D. Messner. New York: Praeger Publishers, 1988.

4. Benjamin, John D., G. Donald Jud, and Daniel T. Winkler, "An Analysis of Shopping Center Investment." Journal of Real Estate Finance and Economics, December 1994.

5. Birch, David L. "America's Office Needs: 1985-1995." Chicago: Arthur Anderson \& Co., 1986.

6. Blinder, Alan S., "More on the Speed of Adjustment in Inventory Models." Journal of Money, Credit, and Banking, August 1986, 355-65.

7. Brueckner, Jan K. and Alfredo M. Pereira. "Housing Wealth and the Economy's Adjustment to Unanticipated Shocks." Working Paper, University of Illinois, August 1993.

8. Byrne, Therese E. and Sandon J. Goldberg. "London and Manhattan: Yield Playgrounds in 'Tried and True' Cities." United States Real Estate Research, U.S. Office Market, New York: Salomon Brothers, Inc., September 1992.

$\rightarrow$ Case, K. E. and R. J. Shiller, "The Efficiency of the Market for Single Family Homes." American Economic Review, March 1989, 125-37. ter 1994

10. Cauley, S. D., "Contingent Price Contracts and the Efficiency of Housing Markets." AREUEA Journal, Win-

11. Clapp, John M. Dynamics of Office Markets. AREUEA Monograph Series, No. 1. Washington, D.C.: The Urban Institute Press, 1993.

12. DeBondt, Werner F. M. "Real Estate Cycles and Animal Spirits." University of Wisconsin, August 1993.

13. Geltner, David, "Bias in Appraisal Based Returns." AREUEA Journal, Fall 1989, 338-52.

14. Giliberto, S. Michael, "A Note on the Use of Appraisal Data in Indexes of Performance Measurement." AREUEA Journal, Spring 1988, 77-83.

15. Griliches, Zvi, “Distributed Lags: A Survey.” Econometrica, January 1967, 16-49.

16. Hendershott, Patric H. and Edward J. Kane, "Causes and Consequences of the 1980s Commercial Real Estate Boom." Journal of Applied Corporate Finance, May 1992, 61-70.

$\rightarrow$ Katz, Lawrence and Kenneth T. Rosen, "The Interjurisdictional Effects of Growth Controls on Housing Prices." Journal of Law and Economics, April 1987, 149-60. Co., 1936.

18. Keynes, John Maynard. The General Theory of Employment Interest and Money. New York: Harcourt Brace and

19. Kling, John L. and Tom McCue, "Office Building Investment and the Macroeconomy: Empirical Evidence." AREUEA Journal, Fall 1987, 234-44. 293-304.

20. — , "Stylized Facts About Industrial Property Construction." Journal of Real Estate Research, Fall 1991,

21. Maccini, Louis J. and Robert J. Rossana, "Joint Production, Quasi-Fixed Factors of Production, and Investment in Finished Goods Inventories.” Journal of Money, Credit, and Banking, May 1984, 218-36. 
22. Muth, Richard F. "The Demand for Non-Farm Housing," in The Demand for Durable Goods, edited by A. C. Harberger. Chicago: University of Chicago Press, 1960, pp. 29-96.

23. Rosen, Kenneth T., "Toward a Model of the Office Building Sector." AREUEA Journal, Fall 1984, 261-69.

$\rightarrow-$ and Lawrence B. Smith, "The Price-Adjustment Process for Rental Housing and the Natural Vacancy Rate." American Economic Review, September 1983, 779-86.

25. Rydell, C. P. "Price Elasticities of Housing Supply." Rand Report, r-286-HUD. Santa Monica, Calif: The Rand Corporation, 1982.

26. Salomon Brothers. "Commercial Banks and Real Estate: Sifting Through the Rubble." Bond Market ResearchReal Estate. New York: Salomon Brothers Inc., October 1991.

27. Shilling, James D., C. F. Sirmans, and John B. Corgel, "Price Adjustment Process for Rental Office Space." Journal of Urban Economics, July 1987, 90-100. $1992,4$.

28. Siegel, Jeremy J., "The Real Estate-Induced Recession.” Economic Outlook, Wharton Real Estate Center, Spring

29. Voith, Richard and Theodore Crone, "National Vacancy Rates and the Persistence of Shocks in U.S. Office Markets." AREUEA Journal, Winter 1988, 437-58.

$\rightarrow$ Wheaton, William C., "Vacancy, Search, and Prices in a Housing Market Matching Model." Journal of Political Economy, 1990, 199-210.

31. — and Raymond G. Torto, "An Investment Model of the Demand and Supply for Industrial Real Estate." AREUEA Journal, Winter 1990, 530-47.

32. — and - "Office Rent Indices and Their Behavior Over Time." Center for Real Estate, Massachusetts Institute of Technology, 1992. 